\title{
Analisis Persaingan Pasar Saham dengan Cryptocurrency dengan Game Theory
}

\author{
Muhammad Anton 1, Carty Irawan ${ }^{2}$, Dede Sukmawan ${ }^{3}$ \\ Program Studi Sistem Informasi Universitas Nusa Putra \\ Jl Raya Cibatu Cisaat no 21 Cibolang Kaler, Sukabumi \\ e-mail: Muhammad.anton@nusaputra.ac.id, carti.irawan@nusaputra.ac.id, dede.sukmawan@ nusaputra.ac.id, \\ * Korespondensi: e-mail: Muhammad.anton@ nusaputra.ac.id
}

\begin{abstract}
Abstrak
Penelitian ini dilatarbelakangi oleh perdebatan instrumen investasi mana yang terbaik, yaitu Saham atau Cryptocurrency. Tujuan penelitian ini dilakukan untuk mencari tahu strategi mana yang optimal untuk kedua permasalahan tersebut menggunakan Game Theory. Dataset dikumpulkan melalui Google Form yang disebarkan di grup Telegram dan Facebook Saham dan Cryptocurrency. Sebelum dianalisa dengan Game Theory dilakukan harus sudah melalui Uji Validitas dan Uji Reliabilitas agar mengetahui strategi mana yang tidak valid. Setelah dilakukannya analisis ditemukan hasil dengan menggunakan Strategi Murni, yang dimana diambil 2 sudut pandang, yaitu Saham yang diunggulkan dan Crypto yang diunggulkan. Maka dengan penelitian ini, dapat terjawab strategi mana yang terbaik untuk kedua jenis instrumen investasi tersebut.
\end{abstract}

Kata Kunci: Saham, Cryptocurrency, Game Theory, Uji Validitas, Uji Reliabilitas.

\begin{abstract}
The research is set back by the debate over which investment instruments are the best, which are stock or cryptocurrency. The purpose of this research is to find out which of the optimum strategies for these two issues by using game theory. The collected data is through Google Form, which is shared by telegram and facebook groups about stock and cryptocurrency. Before analysis with a game theory is done it must went through validity tests and reliability tests to find out which strategies had invalid data. After analysis was done with the results using a pure strategy, taken from two perspectives, which is the underdog being stock and the underdog being crypto. So with this research, it could be surmised which strategies are best for both types of investment instruments.
\end{abstract}

Keywords: Stocks, Cryptocurrency, Game Theory, Validity Test, Reliability Test. 


\section{I.PENDAHULUAN}

Di zaman saat ini dengan teknologi semakin berkembang membuat banyak kemajuan di berbagai bidang termasuk di bidang ekonomi. Salah satu kemajuan yang dapat kita rasakan adalah munculnya instrumen investasi Saham dan Cryptocurrency [1].

Investasi adalah kegiatan menyimpan atau menanamkan modal dengan harapan mendapat keuntungan di masa mendatang. Hal ini membuat banyak orang yang sudah matang secara finansial berupaya mencari investasi terbaik untuk mengamankan aset mereka.Saat ini sudah banyak orang mulai mengalokasikan dananya untuk berinvestasi[2].

Saham sendiri merupakan instrumen investasi yang dimana seseorang melakukan pendanaan pada perusahaan dan merupakan investasi bagi investor. Saham sendiri dapat dilakukan semua orang tanpa memikirkan status, umur dan lain-lain. Saham sendiri merupakan jenis investasi yang berisiko tinggi ketimbang instrumen investasi seperti obligasi, pasar uang dan emas. Dibalik resiko tinggi tersebut, saham juga dapat memberikan keuntungan cukup besar baik dari dividen ataupun kenaikan harga saham.

Cryptocurrency merupakan sebuah mata uang digital atau virtual yang dirancang sebagai alat tukar. Dimana saat ini cryptocurrency yang berfungsi sebagai alat tukar sekarang digunakan sebagai instrumen investasi. Cryptocurrency menggunakan sistem kriptografi untuk mengamankan dan memverifikasi setiap setiap transaksi, serta untuk mengontrol pembuatan unit-unit baru dari suatu cryptocurrency tertentu .

Banyaknya instrumen investasi saat ini termasuk saham dan cryptocurrency, membuat kita harus lebih pandai dalam memilih instrumen investasi mana yang paling sesuai dengan kebutuhan kita. Tiap-tiap instrumen investasi tersebut menawarkan mekanisme, keuntungan, dan risiko yang berbeda-beda.

Tujuan penelitian ini pun untuk mencari tahu strategi paling optimal pada Saham dan Cryptocurrency dikarenakan kedua instrumen tersebut sering dibanding-bandingkan untuk menghasilkan keuntungan terbaik.Untuk itu kami menggunakan teori permainan sebagai metode untuk mengambil keputusan mana strategi paling optimal pada saham dan Cryptocurrency. 


\section{PENELITIAN TERKAIT}

1. Investasi

Investasi adalah salah satu cara dalam mengembangkan uang atau harta dalam jangka waktu tertentu untuk memperoleh keuntungan dimasa depan.Investasi banyak jenisnya seperti reksadana,emas,obligasi,saham,cryptocurrency,tanah atau properti.Melakukan investasi juga didasari dengan banyak tujuan seperti untuk memperoleh penghasilan tetap,untuk menabung atau juga untuk membantu sebuah bisnis agar tetap berjalan.Dari tujuan-tujuan tersebut didapatkan manfaat seperti nilai uang yang diinvestasikan bertambah sehingga tidak terpengaruhi oleh inflasi lalu kita juga mendapat kebebasan secara finansial.

2. Saham

Saham adalah tanda bukti kepemilikan individu atau instansi pada suatu perusahaan perseroan terbatas.Saham tersebut memiliki bentuk lembaran surat berharga yang berisi bahwa pemilik dari surat berharga tersebut adalah pemilik perusahaan yang mengeluarkan surat berharga.Terdapat banyak jenis-jenis saham seperti blue chip stocks, income stocks, growth stocks, speculative stocks, cyclical stocks, emerging growth stock dan defensive stocks. Terdapat dua keuntungan yang bisa didapatkan oleh investor dalam melakukan investasi saham yaitu capital gain dan dividen [3].

\section{Cryptocurrency}

Cryptocurrency merupakan suatu mata uang digital. Memiliki basis data terdistribusi berupa blockchain yang bertipe konsensus yang mencerminkan derajat desentralisasi sistem. Cryptocurrency memiliki sistem terbuka yang mengizinkan siapapun bergabung ke dalam sistem dan keluar dari sistem kapanpun diinginkan serta sistem yang transparan[4].

4. Uji Validitas

Uji validitas merupakan suatu ukuran yang menunjukkan bahwa variabel yang diukur memang benar-benar variabel yang hendak diteliti oleh peneliti,dimana pada konteks membuat kuesioner suatu uji validitas digunakan untuk mengukur sah atau valid tidaknya suatu kuesioner.Suatu tes dapat dikatakan memiliki validitas yang tinggi jika tes tersebut menjalankan fungsi ukurnya.Untuk melakukan uji validitas ini menggunakan program SPSS.Teknik pengujian yang sering digunakan para peneliti untuk uji validitas adalah menggunakan korelasi Bivariate Pearson. Analisis ini dengan cara mengkorelasikan masing-masing skor item dengan skor total.Skor total adalah penjumlahan dari keseluruhan item.Item-item tersebut mampu memberikan dukungan dalam mengungkap apakah valid atau tidak.Jika $r$ hitung $\geq r$ tabel (uji 2 sisi dengan sig. 0,05) maka instrumen atau item-item pertanyaan berkorelasi signifikan terhadap skor total atau bisa dinyatakan valid [5]. 


\section{Uji Reliabilitas}

Reliabilitas menunjuk pada suatu pengertian bahwa instrumen yang digunakan dalam penelitian untuk memperoleh informasi yang digunakan dapat dipercaya sebagai alat pengumpulan data dan mampu mengungkap informasi yang sebenarnya dilapangan.Suatu kuesioner dikatakan reliabel atau handal jika jawaban seseorang terhadap pernyataan adalah konsisten atau stabil dari waktu ke waktu.Tinggi rendahnya reliabilitas,secara empirik ditunjukan oleh suatu angka yang disebut nilai koefisien reliabilitas.Reliabilitas yang tinggi ditunjukan dengan nilai alpha yang mendekati angka 1.Jika nilai cronbach alpha $>0.60$ maka kuesioner atau angket dapat dinyatakan reliabel sedangkkan nilai cronbach alpha $<0.60$ maka kuesioner atau angket dinyatakan tidak reliabel atau tidak konsisten [6].

\section{Game Theory}

Game theory adalah merupaan suatu model matematikka yang digunakan situasi konflik atau persaingan antara berbagai kepentingan yang saling berhadapan sebagai pesaing.Teori ini dikembangkan untuk menganalisis proses pengambilan keputusan dari situasi persaingan yang berbeda-beda dan melibatkan dua atau lebih kepentingan.Jenis persaingan ini ada dalam semua jenis kegiatan,olah raga ,bisnis dan dalam strategi militer.Bentuk umum yang digunakan untuk mencirian permainan yaitu situasi umum dari persaingan sepanjang waktu [7].

Dalam permainan,peserta adalah pesaing.Keuntungan bagi yang satu merupakan kerugian yang lain.Tiap peserta memilih dan melaksanakan strategistrateginya yang ia percaya akan menghasilkan "kemenangan".Dalam permainan,pemain membuat logika yang deduktif dan induktif dalam menentukan pilihan strategi untuk kemenangan.Anggapannya setiap pemain mempunyai kemampuan untuk mengambil keputusan secara bebas dan rasional

Model-model permainan dapat dibedakan berdasarkan jumlah pemain,jumlah keuntungan atau kerugian dan jumlah strategi yang digunakan dalam permainan.Bila jumlah pemain ada dua,permainan disebut sebagai permainan dua pemain.Bila jumlah keuntungan dan kerugian adalah nol,disebut jumlah nol.

\section{METODOLOGI PENELITIAN}

Tahapan prosedur analisis persaingan pasar saham dan cryptocurrency yang dilakukan terdiri dari:

1. Identifikasi masalah

Identifikasi masalah diawali dengan menentukan latar belakang, rumusan dan batasan asumsi.

2. Pengumpulan data

Pengumpulan data dilakukan dengan menggunakan google form yang disebarkan melalui grup pengguna saham dan crypto.

3. Pengolahan data

Pengolahan data diawali dengan uji validitas dan reliabilitas. Setelah itu hasil pertanyaan yang valid akan diolah menggunakan Game Theory. 
JURSISTEKNI (Jurnal Sistem Informasi dan Teknologi Informasi) Vol 4, No.1, January 2022: Hal 28 - 38 ISSN.

P: 2715-1875, E: 2715-1883

\section{HASIL DAN PEMBAHASAN}

Pada bab Hasil \& Pembahasan, akan dibahas secara rinci tahap-tahap dari Metodologi Penelitian kami sebelumnya. Software yang dipakai untuk mengolah adalah Excel dan SPSS.Berikut adalah pemaparan dari setiap metodologi penelitian:

\section{Pengumpulan Data}

Pengumpulan data dilakukan dengan menggunakan google form yang disebarkan melalui grup pengguna Saham dan Crypto. Form yang kami buat bisa dilihat di link berikut: https://forms.gle/jvtkE3Z7pnKwF4dC7. Untuk penilaiannya kami menggunakan skala likert dalam skala 1 sampai 5. Data yang telah dikumpulkan dimasukan kedalam excel untuk diolah ke tahap selanjutnya.

\section{Opsi Cryptocurrency}

\begin{tabular}{|c|c|c|c|c|c|c|c|c|c|}
\hline Sudah berapa la & Apakah anda se & Apakah anda se & Apakah anda se & Apakah menurut & Apakah menury & Apakah menuru & Apakah menurut & Berapa kisaran k & Total \\
\hline 2 & 3 & 2 & 4 & 3 & 5 & 4 & 3 & 2 & 28 \\
\hline 3 & 4 & 3 & 5 & 3 & 5 & 4 & 3 & 3 & 33 \\
\hline 3 & 1 & 1 & 5 & 2 & 5 & 1 & 2 & 3 & 23 \\
\hline 1 & 1 & 1 & 5 & 1 & 5 & 5 & 1 & 3 & 23 \\
\hline 2 & 5 & 1 & 5 & 1 & 5 & 5 & 1 & 3 & 28 \\
\hline 4 & 3 & 3 & 4 & 3 & 4 & 4 & 3 & 4 & 32 \\
\hline 5 & 3 & 3 & 2 & 3 & 5 & 5 & 1 & 4 & 31 \\
\hline 1 & 2 & 1 & 2 & 2 & 5 & 4 & 2 & 4 & 23 \\
\hline 3 & 3 & 3 & 4 & 4 & 5 & 4 & 2 & 4 & 32 \\
\hline 3 & 5 & 1 & 5 & 2 & 5 & 5 & 1 & 4 & 31 \\
\hline 1 & 1 & 1 & 5 & 1 & 5 & 5 & 1 & 4 & \\
\hline 4 & 4 & 2 & 2 & 2 & 4 & 3 & 1 & 5 & \\
\hline 1 & 5 & 5 & 2 & 3 & 5 & 5 & 5 & 5 & \\
\hline 3 & 5 & 5 & 5 & 2 & 5 & 5 & 1 & 5 & 36 \\
\hline 1 & 5 & 5 & 5 & 2 & 5 & 5 & 5 & 5 & 38 \\
\hline 4 & 5 & 5 & 5 & 1 & 5 & 5 & 1 & 5 & 36 \\
\hline 2 & 4 & 1 & 3 & 3 & 5 & 4 & 1 & 5 & 28 \\
\hline 5 & 5 & 5 & 5 & 2 & 5 & 5 & 1 & 5 & 38 \\
\hline 1 & 5 & 5 & 5 & 3 & 5 & 5 & 1 & 5 & 35 \\
\hline 5 & 5 & 5 & 5 & 1 & 5 & 5 & 1 & 5 & 37 \\
\hline
\end{tabular}

Gambar 1. Data Kuisioner Cryptocurrency

Opsi Saham

\begin{tabular}{|c|c|c|c|c|c|c|c|c|c|}
\hline Sudah berapa la & Apakah anda se & Apakah anda se & Apakah anda se & Apakah menurut & Apakah menurut & Apakah menurut & Apakah menurut & Berapa kisaral & Total \\
\hline 1 & 2 & 2 & 4 & 2 & 3 & 3 & 2 & 4 & 23 \\
\hline 3 & 4 & 4 & 4 & 2 & 3 & 3 & 3 & 3 & 29 \\
\hline 1 & 1 & 1 & 1 & 5 & 4 & 3 & 4 & 3 & 23 \\
\hline 1 & 5 & 5 & 5 & 3 & 4 & 4 & 4 & 4 & 35 \\
\hline 1 & 4 & 2 & 3 & 2 & 2 & 4 & 2 & 4 & 24 \\
\hline 2 & 3 & 4 & 3 & 3 & 3 & 4 & 4 & 3 & 29 \\
\hline 4 & 5 & 5 & 1 & 5 & 5 & 3 & 1 & 5 & 34 \\
\hline 3 & 5 & 1 & 5 & 5 & 4 & 5 & 1 & 2 & 31 \\
\hline 5 & 5 & 5 & 5 & 5 & 5 & 5 & 1 & 5 & 41 \\
\hline 2 & 2 & 4 & 3 & 2 & 2 & 4 & 3 & 3 & 25 \\
\hline 5 & 5 & 2 & 5 & 5 & 3 & 5 & 1 & 4 & 35 \\
\hline 5 & 5 & 5 & 5 & 5 & 3 & 5 & 1 & 5 & 39 \\
\hline 2 & 1 & 1 & 1 & 5 & 4 & 5 & 1 & 1 & 21 \\
\hline 3 & 5 & 1 & 5 & 5 & 4 & 5 & 1 & 4 & 33 \\
\hline 4 & 3 & 1 & 4 & 4 & 5 & 5 & 1 & 4 & 31 \\
\hline 1 & 1 & 1 & 2 & 5 & 5 & 5 & 1 & 2 & 23 \\
\hline
\end{tabular}


JURSISTEKNI (Jurnal Sistem Informasi dan Teknologi Informasi) Vol 4, No.1, January 2022: Hal 28 - 38 ISSN.

Opsi Keduanya : Crypocurrency dan Saham

\begin{tabular}{|c|c|c|c|c|c|c|c|c|c|}
\hline \multicolumn{10}{|c|}{ Keduanya : Saham } \\
\hline Sudah berapa la & Apakah anda s & \begin{tabular}{|l|} 
Apakah anda s \\
\end{tabular} & Apakah anda s & Apakah menurut & ut Apakah menuru & Apakah menuru & Apakah menuru & Berapa kisara & Total \\
\hline 5 & 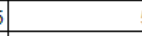 & 3 & 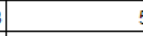 & 4 & 2 & 5 & 2 & 3 & 34 \\
\hline 4 & 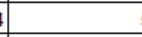 & 2 & 2 & 4 & 5 & 4 & 2 & 4 & 32 \\
\hline 4 & 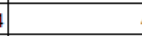 & 1 & 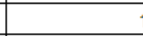 & 4 & 4 & 4 & 3 & 3 & 28 \\
\hline 2 & 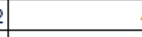 & 5 & - & 5 & 4 & 4 & 1 & 3 & 30 \\
\hline 5 & 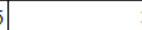 & 1 & 5 & 5 & 3 & 5 & 5 & 5 & 37 \\
\hline 4 & 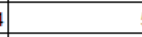 & 1 & 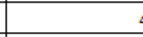 & 5 & 3 & 5 & 1 & 3 & 31 \\
\hline 5 & 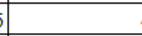 & 5 & 3 & 3 & 3 & 4 & 3 & 5 & 35 \\
\hline 5 & 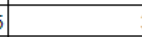 & 1 & 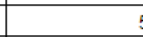 & 4 & 4 & 5 & 1 & 4 & 32 \\
\hline 1 & 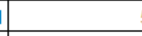 & 1 & & 5 & 3 & 5 & 1 & 3 & 29 \\
\hline 5 & 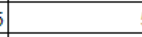 & 1 & 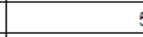 & 5 & 5 & 5 & 1 & 5 & 37 \\
\hline 3 & 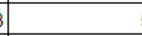 & 1 & 2 & 5 & 3 & 5 & 1 & 2 & 27 \\
\hline 5 & 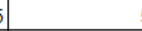 & 5 & & 5 & 3 & 5 & 1 & 4 & 38 \\
\hline 3 & 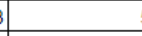 & 1 & 3 & 5 & 3 & 5 & 1 & 2 & 28 \\
\hline 5 & 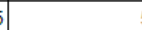 & 1 & 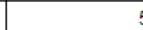 & 5 & 4 & 5 & 1 & 5 & 36 \\
\hline
\end{tabular}

Keduanya : Crypto

\begin{tabular}{|c|c|c|c|c|c|c|c|c|c|}
\hline Sudah berapa la & Apakah anda se & Apakah anda se & Apakah anda se & Apakah menurut & Apakah menuru & Apakah menurut & Apakah menurut & Berapa kisaral & Total \\
\hline 5 & 4 & 5 & 5 & 3 & 5 & 5 & 2 & 3 & 37 \\
\hline 2 & 5 & 5 & 4 & 2 & 5 & 4 & 1 & 5 & 33 \\
\hline 3 & 4 & 1 & 3 & 3 & 5 & 4 & \begin{tabular}{l|l}
3 & \\
\end{tabular} & 4 & 30 \\
\hline 3 & 4 & 4 & 4 & 3 & 5 & 4 & 1 & 3 & 31 \\
\hline 5 & 3 & 1 & 5 & 1 & 5 & 5 & 5 & 4 & 34 \\
\hline 1 & 5 & 1 & 4 & 2 & 5 & 5 & 1 & 4 & 28 \\
\hline 3 & 3 & 4 & 4 & 4 & 4 & 5 & 4 & 4 & 35 \\
\hline 5 & 5 & 1 & 5 & 2 & 5 & 5 & 1 & 5 & 34 \\
\hline 1 & 5 & 1 & 5 & 1 & 2 & 5 & 1 & 3 & 24 \\
\hline 5 & 5 & 1 & 5 & 2 & 5 & 5 & 1 & 5 & 34 \\
\hline 1 & 5 & 1 & 2 & 2 & 5 & 5 & 1 & 3 & 25 \\
\hline 2 & 5 & 5 & 5 & 1 & 5 & 5 & 1 & \begin{tabular}{l|l}
5 \\
\end{tabular} & 34 \\
\hline 1 & 5 & 1 & 3 & 1 & 5 & 5 & $3 \mid$ & 3 & 27 \\
\hline 1 & 5 & 1 & 5 & 1 & 5 & 5 & 1 & 4 & 28 \\
\hline
\end{tabular}

Gambar 2. Data Kuisioner Saham dan Cryptocurrency

1. Uji Validitas dan Reliabilitas

\section{Uji Validitas}

Kami menggunakan SPSS untuk menguji validitas dan reliabilitas. Data yang digunakan berasal dari form yang telah kami sebarkan. Uji validitas bertujuan untukmengetahui kevalidan atau kesesuaian kuesioner. $\mathrm{N}$ yang digunakan adalah 64 dan mendapatkan nilai $r$ tabel 0.242 . 
JURSISTEKNI (Jurnal Sistem Informasi dan Teknologi Informasi) Vol 4, No.1, January 2022: Hal 28 - 38 ISSN.

P: 2715-1875, E: 2715-1883

\begin{tabular}{|c|c|c|c|c|c|c|c|c|c|c|c|}
\hline \multicolumn{12}{|c|}{ Correlations } \\
\hline & & \begin{tabular}{|l|} 
Pertanyaan1 \\
\end{tabular} & \begin{tabular}{|l|} 
Pertanyaan2 \\
\end{tabular} & \begin{tabular}{|l|} 
Pertanyaan3 \\
\end{tabular} & \begin{tabular}{|l|} 
Pertanyaan4 \\
\end{tabular} & Pertanyaan5 & Pertanyaan6 & \begin{tabular}{|l|} 
Pertanyaan7 \\
\end{tabular} & \begin{tabular}{|l|} 
Pertanyaan8 \\
\end{tabular} & \begin{tabular}{|l|} 
Pertanyaang \\
\end{tabular} & Total \\
\hline \multirow[t]{3}{*}{ Pertanyaan1 } & Pearson Correlation & 1 & $247^{1}$ & .151 & .232 & $308^{\prime}$ & .050 & .138 & .124 & $.329^{\prime \prime}$ & $.636^{\prime \prime}$ \\
\hline & Sig. (2-tailed) & & .049 & .232 & .065 & .013 & .697 & .277 & .331 & .008 & .000 \\
\hline & $\mathrm{N}$ & 64 & 64 & 64 & 64 & 64 & 64 & 64 & 64 & 64 & 64 \\
\hline \multirow[t]{3}{*}{ Pertanyaan2 } & Pearson Correlation & $.247^{\circ}$ & 1 & $.273^{\circ}$ & $293^{\circ}$ & .033 & .012 & $.387^{\prime \prime}$ & .231 & $366^{\prime \prime}$ & $.604^{\prime \prime}$ \\
\hline & Sig. (2-tailed) & .049 & & .029 & .019 & .796 & .923 & .002 & .067 & .003 & .000 \\
\hline & $\mathrm{N}$ & 64 & 64 & 64 & 64 & 64 & 64 & 64 & 64 & 64 & 64 \\
\hline \multirow[t]{3}{*}{ Pertanyaan3 } & Pearson Correlation & .151 & $.273^{1}$ & 1 & .131 & .074 & .024 & .042 & .150 & $.408^{\prime \prime}$ & $.602^{\prime \prime}$ \\
\hline & Sig. (2-tailed) & .232 & .029 & & .301 & .560 & .853 & .742 & .236 & .001 & .000 \\
\hline & $\mathrm{N}$ & 64 & 64 & 64 & 64 & 64 & 64 & 64 & 64 & 64 & 64 \\
\hline \multirow[t]{3}{*}{ Pertanyaan4 } & Pearson Correlation & .232 & $.293^{\circ}$ & .131 & 1 & .227 & .040 & $.336^{\prime \prime}$ & .143 & $.299^{\prime}$ & $.483^{\prime \prime}$ \\
\hline & Sig. (2-tailed) & .065 & .019 & .301 & & .071 & .752 & .007 & .260 & .016 & .000 \\
\hline & $\mathrm{N}$ & 64 & 64 & 64 & 64 & 64 & 64 & 64 & 64 & 64 & 64 \\
\hline \multirow[t]{3}{*}{ Pertanyaan5 } & Pearson Correlation & $.308^{\prime}$ & .033 & .074 & .227 & 1 & $.309^{\prime}$ & .061 & .069 & .212 & .203 \\
\hline & Sig. (2-tailed) & .013 & .796 & .560 & .071 & & .013 & .629 & .589 & .093 & .108 \\
\hline & $\mathrm{N}$ & 64 & 64 & 64 & 64 & 64 & 64 & 64 & 64 & 64 & 64 \\
\hline \multirow[t]{3}{*}{ Pertanyaan6 } & Pearson Correlation & .050 & .012 & .024 & .040 & $.309^{\prime}$ & 1 & .058 & .111 & $.268^{1}$ & .143 \\
\hline & Sig. (2-tailed) & 697 & .923 & .853 & .752 & .013 & & .651 & .384 & .032 & .261 \\
\hline & N & 64 & 64 & 64 & 64 & 64 & 64 & 64 & 64 & 64 & 64 \\
\hline \multirow[t]{3}{*}{ Pertanyaan7 } & Pearson Correlation & .138 & $.387^{\prime \prime}$ & .042 & $.336^{\prime \prime}$ & .061 & .058 & 1 & .226 & .074 & $.367^{\prime \prime}$ \\
\hline & Sig. (2-tailed) & .277 & .002 & .742 & .007 & .629 & .651 & & .072 & .562 & .003 \\
\hline & N & 64 & 64 & 64 & 64 & 64 & 64 & 64 & 64 & 64 & 64 \\
\hline \multirow[t]{3}{*}{ Pertanyaan8 } & Pearson Correlation & .124 & .231 & .150 & .143 & .069 & .111 & .226 & 1 & .004 & .090 \\
\hline & Sig. (2-tailed) & .331 & .067 & .236 & .260 & .589 & .384 & .072 & & .978 & .481 \\
\hline & N & 64 & 64 & 64 & 64 & 64 & 64 & 64 & 64 & 64 & 64 \\
\hline \multirow[t]{3}{*}{ Pertanyaang } & Pearson Correlation & $329^{\prime \prime}$ & $.366^{\prime \prime}$ & $.408^{\prime \prime}$ & $299^{\prime}$ & .212 & $.268^{\prime}$ & .074 & .004 & 1 & $.633^{\prime \prime}$ \\
\hline & Sig. (2-tailed) & .008 & .003 & .001 & .016 & .093 & .032 & .562 & .978 & & .000 \\
\hline & $\mathrm{N}$ & 64 & 64 & 64 & 64 & 64 & 64 & 64 & 64 & 64 & 64 \\
\hline \multirow[t]{3}{*}{ Total } & Pearson Correlation & $.636^{\prime \prime}$ & $604^{\prime \prime}$ & $.602^{\prime \prime}$ & $.483^{\prime \prime}$ & .203 & .143 & $.367^{\prime \prime}$ & .090 & $.633^{\prime \prime}$ & 1 \\
\hline & Sig. (2-tailed) & .000 & .000 & .000 & .000 & .108 & .261 & .003 & .481 & .000 & \\
\hline & $\mathrm{N}$ & 64 & 64 & 64 & 64 & 64 & 64 & 64 & 64 & 64 & 64 \\
\hline
\end{tabular}

Gambar 3. Uji Validitas

\begin{tabular}{|c|c|c|c|}
\hline \multicolumn{4}{|c|}{ Uji Validitas dilakukan dengan bantuan APP SPSS } \\
\hline $\mathrm{n}=64$ & & & \\
\hline Subjek & R Hitung & R Tabel & Interpretasi \\
\hline 1 & 0.636 & 0.242 & Valid \\
\hline 2 & 0.604 & 0.242 & Valid \\
\hline 3 & 0.602 & 0.242 & Valid \\
\hline 4 & 0.483 & 0.242 & Valid \\
\hline 5 & 0.203 & 0.242 & Tidak Valid \\
\hline 6 & 0.143 & 0.242 & Tidak Valid \\
\hline 7 & 0.085 & 0.242 & Tidak Valid \\
\hline 8 & 0.166 & 0.242 & Tidak Valid \\
\hline 9 & 0.633 & 0.242 & Valid \\
\hline
\end{tabular}

Gambar 4. Uji Validitas APP 
JURSISTEKNI (Jurnal Sistem Informasi dan Teknologi Informasi) Vol 4, No.1, January 2022: Hal 28 - 38 ISSN.

$P: 2715-1875, E: 2715-1883$

Terdapat 4 pertanyaan yang tidak valid dimana pertanyaan tersebut tidak akan dimasukan ke uji reliabilitas.

\section{Uji Reliabilitas}

Uji reliabilitas digunakan untuk mengetahui konsistensi angket.Data yang dimasukkan untuk di uji reliabilitas nya adalah data yang valid berdasarkan uji validitas sebelumnya.

\begin{tabular}{|c|c|c|c|c|}
\hline \multicolumn{2}{|c|}{ Reliability Statistics } & & & \\
\hline $\begin{array}{c}\text { Cronbach's } \\
\text { Alpha }\end{array}$ & $\mathrm{N}$ of Items & & & \\
\hline 625 & 5 & & & \\
\hline \multicolumn{5}{|c|}{ Item-Total Statistics } \\
\hline & $\begin{array}{l}\text { Scale Mean if } \\
\text { Item Deleted }\end{array}$ & $\begin{array}{c}\text { Scale } \\
\text { Variance if } \\
\text { Item Deleted }\end{array}$ & $\begin{array}{l}\text { Corrected } \\
\text { Item-Total } \\
\text { Correlation } \\
\end{array}$ & $\begin{array}{c}\text { Cronbach's } \\
\text { Alpha if Item } \\
\text { Deleted }\end{array}$ \\
\hline Pertanyaan1 & 14.28 & 13.507 & .333 & .597 \\
\hline Pertanyaan 2 & 13.27 & 13.754 & .434 & .544 \\
\hline Pertanyaan 3 & 14.73 & 12.738 & .331 & .608 \\
\hline Pertanyaan 4 & 13.34 & 14.674 & .334 & .592 \\
\hline Pertanyaan 9 & 13.44 & 14.472 & .549 & .518 \\
\hline
\end{tabular}

\section{Gambar 5. Uji Reliabilitas}

Dapat dilihat dari gambar diatas nilai Cronbach Alpha yaitu 0.625 lebih besar dari 0.60 maka dapat dinyatakan bahwa maka kuesioner atau angket dinyatakan reliabe.

\section{Game Theory}

Setelah melewati uji validitas dan uji reliabilitas, data dimasukkan ke tabel game theory untuk ditemukan saddle pointnya. Disini kami membuat 2 perspektif yaitu kalau crypto diuntungkan dan kalau saham diuntungkan

Tabel 1. Tabel Game untuk Mencari Sadle Point

\begin{tabular}{|c|c|c|c|c|c|c|c|c|c|}
\hline \multirow{2}{*}{$\begin{array}{l}\text { Tabel Data } \\
\text { Total }\end{array}$} & \multicolumn{9}{|c|}{ Variabel: } \\
\hline & 1 & 2 & 3 & 4 & 5 & 6 & 7 & 8 & 9 \\
\hline Nilai Crypto & 54 & 74 & 58 & 83 & 44 & 98 & 88 & 37 & 83 \\
\hline Nilai Saham & 43 & 56 & 44 & 56 & 63 & 59 & 68 & 31 & 56 \\
\hline \multicolumn{10}{|c|}{ Dari keduanya } \\
\hline Saham & 56 & 63 & 28 & 53 & 64 & 49 & 24 & 66 & 51 \\
\hline Crypto & 38 & 63 & 32 & 59 & 28 & 66 & 26 & 67 & 55 \\
\hline \multicolumn{10}{|l|}{ Total Duanya } \\
\hline Crypto & 92 & 137 & 90 & 142 & 72 & 164 & 114 & 104 & 138 \\
\hline Saham & 99 & 119 & 72 & 109 & 127 & 108 & 92 & 97 & 107 \\
\hline
\end{tabular}


JURSISTEKNI (Jurnal Sistem Informasi dan Teknologi Informasi) Vol 4, No.1, January 2022: Hal 28 - 38 ISSN.

P: 2715-1875, E: 2715-1883

Nilai baris dan kolom:

Nilai pihak yang diuntungkan - nilai pihak yang dirugikan.

Table 2. Table Saham

\begin{tabular}{|c|c|c|c|c|c|c|c|c|c|c|c|}
\hline & \multicolumn{10}{|c|}{ Crypto } & \\
\hline \multirow{11}{*}{ Saham } & & y1 & y2 & y3 & $\mathrm{y} 4$ & $\mathrm{y} 5$ & y6 & y7 & y8 & y9 & Angka Min \\
\hline & $\mathrm{x} 1$ & 7.00 & -38.00 & 9.00 & -43.00 & 27.00 & -65.00 & -15.00 & -5.00 & -39.00 & -65.00 \\
\hline & $\mathrm{x} 2$ & 27.00 & -18.00 & 29.00 & -23.00 & 47.00 & -45.00 & 5.00 & 15.00 & -19.00 & -45.00 \\
\hline & $\mathrm{x} 3$ & -20.00 & -65.00 & -18.00 & -70.00 & 0.00 & -92.00 & -42.00 & -32.00 & -66.00 & -92.00 \\
\hline & $\mathrm{x} 4$ & 17.00 & -28.00 & 19.00 & -33.00 & 37.00 & -55.00 & -5.00 & 5.00 & -29.00 & -55.00 \\
\hline & $x 5$ & 35.00 & -10.00 & 37.00 & -15.00 & 55.00 & -37.00 & 13.00 & 23.00 & -11.00 & -37.00 \\
\hline & x6 & 16.00 & -29.00 & 18.00 & -34.00 & 36.00 & -56.00 & -6.00 & 4.00 & -30.00 & -56.00 \\
\hline & $\mathrm{x} 7$ & 0 & -45 & 2 & -50 & 20 & -72 & -22 & -12 & -46 & -72 \\
\hline & $\mathrm{x} 8$ & 5 & -40 & 7 & -45 & 25 & -67 & -17 & -7 & -41 & -67 \\
\hline & x9 & 15 & -30 & 17 & -35 & 35 & -57 & -7 & 3 & -31 & -57 \\
\hline & Angka Max & 35 & -10 & 37 & -15 & 55 & -37 & 13 & 23 & -11 & \\
\hline
\end{tabular}

Tabel 3. Tabel Cryptocurrency

\begin{tabular}{|c|c|c|c|c|c|c|c|c|c|c|c|}
\hline & \multicolumn{10}{|c|}{ Saham } & \multirow[b]{2}{*}{ Angka Min } \\
\hline \multirow{10}{*}{ Crypto } & & $\mathrm{y} 1$ & $\mathrm{y} 2$ & y3 & $\mathrm{y} 4$ & y5 & y6 & y7 & y8 & y9 & \\
\hline & $\mathrm{x} 1$ & -7 & -27 & 20 & -17 & -35 & -16 & 0 & -5 & -15 & -35 \\
\hline & $\mathrm{x} 2$ & 38 & 18 & 65 & 28 & 10 & 29 & 45 & 40 & 30 & 10 \\
\hline & $\mathrm{x} 3$ & -9 & -29 & 18 & -19 & -37 & -18 & -2 & -7 & -17 & -37 \\
\hline & $\mathrm{x} 4$ & 43 & 23 & 70 & 33 & 15 & 34 & 50 & 45 & 35 & 15 \\
\hline & $\times 5$ & -27 & -47 & 0 & -37 & -55 & -36 & -20 & -25 & -35 & -55 \\
\hline & $\mathrm{x} 6$ & 65 & 45 & 92 & 55 & 37 & 56 & 72 & 67 & 57 & 37 \\
\hline & $x 7$ & 15 & -5 & 42 & 5 & -13 & 6 & 22 & 17 & 7 & -13 \\
\hline & $\mathrm{x} 8$ & 5 & -15 & 32 & -5 & -23 & -4 & 12 & 7 & -3 & -23 \\
\hline & $\mathrm{x} 9$ & 39 & 19 & 66 & 29 & 11 & 30 & 46 & 41 & 31 & 11 \\
\hline & $\begin{array}{l}\text { Angka } \\
\text { Max }\end{array}$ & 65 & 45 & 92 & 55 & 37 & 56 & 72 & 67 & 57 & \\
\hline
\end{tabular}


Tabel 5. Nilai Sadle Point Crypthocurrency dan Saham

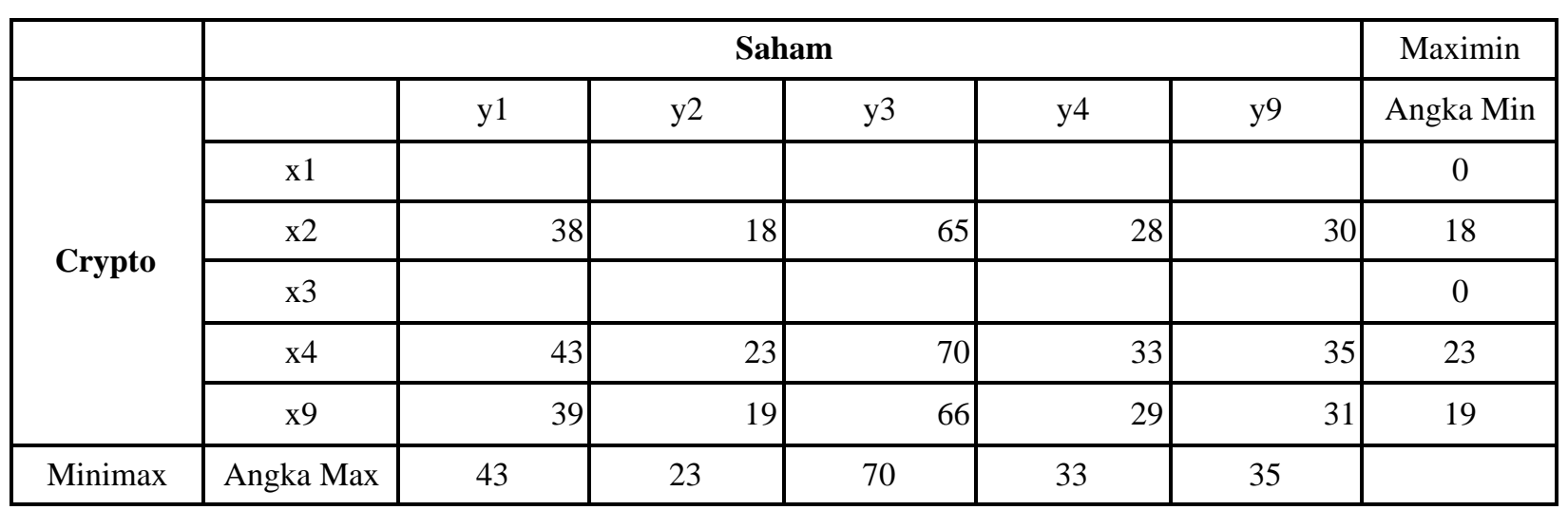

\begin{tabular}{|c|c|c|c|c|c|c|c|}
\hline & \multicolumn{6}{|c|}{ Crypto } & \multirow{2}{*}{$\frac{\text { Maximin }}{\text { Angka Min }}$} \\
\hline \multirow{6}{*}{ Saham } & & $\mathrm{y} 1$ & $\mathrm{y} 2$ & y3 & $\mathrm{y} 4$ & y9 & \\
\hline & $\mathrm{x} 1$ & 7 & & 9 & & & 7 \\
\hline & $\mathrm{x} 2$ & 27 & & 29 & & & 27 \\
\hline & $\mathrm{x} 3$ & & & & & & 0 \\
\hline & $\mathrm{x} 4$ & 17 & & 19 & & & 17 \\
\hline & $\mathrm{x} 9$ & 15 & & 17 & & & 15 \\
\hline Minimax & Angka Max & 27 & 0 & 29 & 0 & 0 & \\
\hline
\end{tabular}

\section{KESIMPULAN}

Berdasarkan hasil analisis Game Theory yang sudah kami lakukan, ditemukan 4 pertanyaan yang tidak valid dari hasil uji validitas, yaitu $\mathrm{N}=64$ dan mendapatkan nilai $\mathrm{r}$ tabel 0.242. Kemudian dilakukannya uji reliabilitas untuk mengetahui apakah data dapat dipercaya atau tidak dan menghasilkan Cronbach Alpha, yaitu 0.625 lebih besar dari 0.6. Sehingga diketahui data yang dikumpulkan konsisten atau dapat dipercaya. Data yang valid dimasukkan kedalam tabel Game Theory dimana tabel dibagi menjadi 2 sudut pandang, yaitu kondisi saham yang lebih diuntungkan dan crypto lebih diuntungkan. Perhitungan dilakukan dengan strategi murni dan menghasilkan saddle point 23 untuk saham lebih diuntungkan, dan 27 untuk crypto lebih diuntungkan. Dikarenakan saddle point telah ditemukan menggunakan strategi murni maka tidak diperlukannya perhitungan dengan strategi campuran. Didapat dari hasil analisis kami, apabila crypto diuntungkan atas saham. Crypto unggul melalui strategi sentimen dimana seperti yang kami ketahui crypto sangat sensitif terhadap sentimen berita baik itu positif atau negatif, untuk meminimalisir kerugiannya saham dapat menggunakan strategi analisis fundamental. Sedangkan dalam kondisi saham diuntungkan, dibutuhkan strategi analisis fundamental untuk mendapatkan keuntungan, dan agar dapat meminimalisir kerugian crypto strategi yang dibutuhkan adalah berapa lama pengguna berinvestasi. 
JURSISTEKNI (Jurnal Sistem Informasi dan Teknologi Informasi) Vol 4, No.1, January 2022: Hal 28 - 38 ISSN.

$P: 2715-1875, E: 2715-1883$

\section{DAFTAR PUSTAKA}

[1] Darmawan, O. (2017). Bitcoin Trading for Z Generation. Jasakom.

[2] Wijaya, D. A. (2018). Bitcoin Mining Dan Cryptocurrency lainnya.... Jasakom.

[3] Hogan, N. (2015). Yuk Nabung Saham. Elex Media Komputindo.

[4] Falentino S.(2021). Analisis Tingkat Akurasi Algoritma Moving Average dalam Prediksi Pergerakan Uang Elektronik Bitcoin. Jutisi: Jurnal Ilmiah Teknik Informatika dan Sistem Informasi.

[5] Dr.Riduwan,M.B.A, \& Dr.Sunarto,M.Si. (2019). Pengantar Statistika untuk

[6] Penelitian Pendidikan, Sosial, Ekonomi, Komunikasi,dan Bisnis. Lengkap dengan Aplikasi Spss 14. Alfabeta Bandung.

[7] Aminudin. (2005). Prinsip-prinsip Riset Operasi. Erlangga. 